JETE : VOL 2 NO 2 2021* E-ISSN : 2745-9888 * P-ISSN : 2745-9896

Journal of Education and Teaching

http://ejournal.uin-suska.ac.id/index.php/JETE

\title{
UPAYA MENINGKATKAN HASIL BELAJAR PESERTA DIDIK MELALUI METODE DISKUSI DALAM PEMBELAJARAN IPS DI KELAS VIIA SMPN 4 TAPUNG HILIR TAHUN PELAJARAN 2019/2020
}

\author{
Yami $^{1}$ \\ SMP Negeri 4 Tapung Hilir Kampar, Indonesia ${ }^{1}$ \\ Email: yamiyami376@ yahoo.com ${ }^{* 1}$
}

Received: 30 Oktober 2019; Accepted 12 Agustus 2021; Published 1 September 2021

Ed 2021; 2 (2): 188-196

\begin{abstract}
ABSTRAK
Berdasarkan rumusan masalah tersebut, maka tujuan yang ingin dicapai dalam penelitian ini adalah sebagai berikut.Untuk mengetahui peningkatan hasil belajar setelah menggunakan metode diskusi, dalam pembelajaran Ilmu Pengetahuan Sosial pokok pembahasan letak dan luas Indonesia di SMPN 4 Tapung Hilir Rancangan penelitian yang ditetapkan dalam penelitian ini adalah penelitian tindakan kelas. Ada empat tahapan dalam penelitian tindakan, yaitu (1) perencanaan, (2) pelaksanaan, (3) pengamatan, dan (4) refleksi. Berdasarkan hasil penelitian yang telah dilakukan terhadap peserta didik kelas VIIA IPS yang berjumlah 20 peserta didik, maka peneliti dapat mengumpulkan data hasil belajar peserta didik melalui tes tertulis. Berikut adalah hasil belajar pre test dan post test peserta didik yang diajar dengan menggunakan metode diskusi. tingkat pengusaan materi peserta didik pada pretest sebagai berikut.nilai 40-46 dengan frekuensi 4 (20\%), nilai $47-53$ dengan frekuensi 5 (25\%), nilai 54-60 dengan frekuensi 4 (20\%), nilai 61-67 dengan frekuensi 2 (10\%), nilai 68-75 dengan frekuensi $5(41,67 \%)$. Berdasarkan data yang diperoleh pada pretest menunjukan bahwa jumlah siswa yang tuntas sebanyak 5 siswa atau (25\%), tidak tuntas sebanyak 15 siswa atau (75\%), sedangkan siklus I siswa yang tuntas sebanyak 15 siswa atau (75\%), dan tidak tuntas 5 siswa atau $(25 \%)$.
\end{abstract}

Kata Kunci: Pengetahuan ; Peserta didik; Hasil belajar

\section{UPAYA MENINGKATKAN HASIL BELAJAR PESERTA DIDIK MELALUI METODE DISKUSI DALAM PEMBELAJARAN IPS DI KELAS VIIA SMPN 4 TAPUNG HILIR TAHUN PELAJARAN 2019/2020}

\begin{abstract}
Based on the formulation of the problem, the objectives to be achieved in this study are as follows. To find out the improvement of learning outcomes after using the discussion method, in learning Social Sciences the main discussion of the location and area of Indonesia in SMPN 4 Tapung Hilir The research design set in this study is classroom action research. There are four stages in action research, namely (1) planning, (2) implementation, (3) observation, and (4) reflection. Based on the results of research conducted on students of Class VIIA IPS, amounting to 20 students, the
\end{abstract}


researcher can collect data on student learning outcomes through written tests. The following are the results of pre-test and post-test learning of students taught using the discussion method. the level of mastery of students' material in the pretest as follows. value 40-46 with a frequency of 4 (20\%), a value of 47 -53 with a frequency of 5 (25\%), a value of 54-60 with a frequency of 4 (20\%), a value of 61-67 with a frequency of 2 (10\%), a value of 68-75 with a frequency of 5 (41.67\%). Based on the data obtained in the pretest shows that the number of students who completed as many as 5 students or (25\%), not complete as many as 15 students or (75\%), while the first cycle of students who completed as many as 15 students or (75\%), and incomplete 5 students or (25\%).

Keywords: Knowledge; Learners; Learning outcomes

\section{PENDAHULUAN}

Pengertian Pendidikan menurut ( Kadir,Dkk, 2012:6 ) adalah usaha sadar yang dilakukan masyarakat dan pemerintah melalui kegiatan bimbingan, pengajaran atau latihan yang berlangsung di sekolah maupun di luar sekolah sepanjang hayat untuk mempersiapkan peserta didik agar dapat memainkan peranan dalam berbagai lingkungan hidup secara tepat pada masa yang akan dating.

Metode pengajaran memiliki kedudukan yang amat strategis dalam mendukung keberhasilan proses belajar mengajar. Itulah sebabnya, para ahli pendidikan sepakat bahwa guru yang ditugaskan mengajar di sekolah haruslah guru yang professional yaitu guru yang antara lain ditandai oleh penguasaan yang prima terhadap metode pengajaranya. Menurut ( Nata, 2014:176 ) Melalui metode pengajaran, mata pelajaran dapat disampaikan secara efesien, efektif dan terukur dengan baik, sehingga dapat dilakukan perencanaan dan perkiraan dengan tepat.

Berdasarkan dari uraian latar belakang di atas dapat diketahui bahwa metode diskusi efektif jika diterapkan dalam mata pelajaran IPS, karena metode ini menarik dan dapat meningkatkan semangat peserta didik. oleh karena itu, peneliti bermaksud ingin meneliti tentang "Upaya meningkatkan hasil belajar peserta didik melalui metode diskusi dalam pembelajaran IPS di kelas VIIA SMPN 4 Tapung Hilir Tahun Pelajaran 2019/2020."

Berdasarkan rumusan masalah tersebut, maka tujuan yang ingin dicapai dalam penelitian ini adalah sebagai berikut.Untuk mengetahui peningkatan hasil belajar setelah menggunakan metode diskusi, dalam pembelajaran Ilmu Pengetahuan Sosial pokok pembahasan letak dan luas Indonesia di SMPN 4 Tapung Hilir. Secara teoritis penelitian ini akan mengkaji metode pembelajaran yang sesuai untuk meningkatkan hasil belajar IPS melalui metode diskusi. Dengan demikian temuan penelitian ini akan memperkaya khasanah pengetahuan di bidang metode pembelajaran.

\section{METODE PENELITIAN}

Rancangan penelitian yang ditetapkan dalam penelitian ini adalah penelitian tindakan kelas. Arikunto (2010:16) menjelaskan ada empat tahapan dalam penelitian tindakan, yaitu (1) perencanaan, (2) pelaksanaan, (3) pengamatan, dan (4) refleksi.

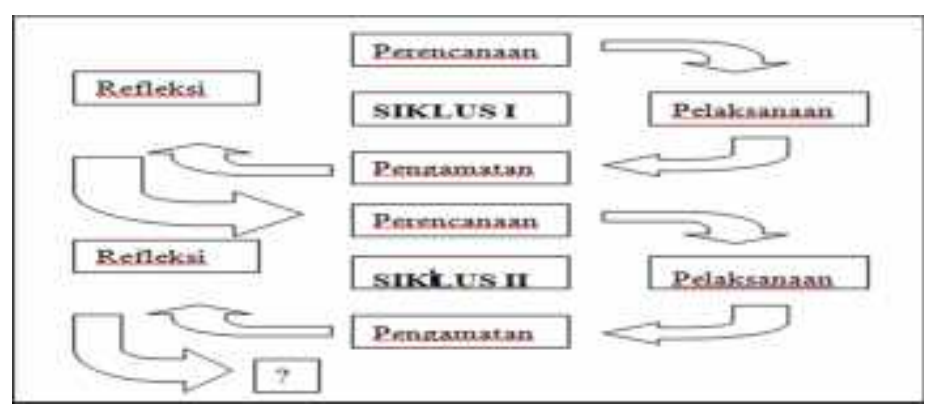


Penelitian dilaksanakan di SMP N 4 Tapung Hilir, kelas VIIA semester satu Tahun Pelajaran 2019/2020.Penelitian ini Siklus I dilakukan tanggal 25 Agustus 2019 dan siklus II pada tanggal 1 September 2019. Dalam penelitian ini, teknik pengumpulan data yang digunakan penulis adalah : 1)Observasi, yaitu pengamatan secara langsung terhadap proses pembelajaran yang berlangsung di kelas. Observasi dilakukan terhadap peserta Didik terkait proses pembelajaran, aktivitas dan interaksinya. Observasi dapat dilakukan menggunakan daftar cek (cheklist) ataupun catatan terbuka (tulisan bebas) tentang pembelajaran. Pedoman observasi menggunakan cek lebih mudah digunakan karena berisi daftar kriteria tertentu, sehingga (pengamat) hanya memberikan tanda cek pada kriteria yang sesuai dengan pengamatan. 2) Tes, Tes dalam penelitian PTK dipergunakan untuk mengukur perkembangan atau kemajuan belajar peserta didik. Sebagai alat pengukur perkembangan dan kemajuan belajar peserta didik. Tes yang dilakukan pada akhir pembelajaran siklus I, siklus II untuk mengukur dan mengkualifikasikan pencapaian/ hasil belajar peserta Didik. Instrumen yang digunakan adalah lembar soal dan hasil pekerjaan peserta didik.

\section{HASIL DAN PEMBAHASAN}

Berdasarkan hasil penelitian yang telah dilakukan terhadap peserta didik kelas VIIA IPS yang berjumlah 20 peserta didik, maka peneliti dapat mengumpulkan data hasil belajar peserta didik melalui tes tertulis. Berikut adalah hasil belajar pre test dan post test peserta didik yang diajar dengan menggunakan metode diskusi.

Tabel 1.1

Data Hasil Belajar Pre Test dan Post Test Peserta Didik

\begin{tabular}{|c|l|c|c|}
\hline \multirow{2}{*}{ No } & \multicolumn{2}{|c|}{ Nama } & \multicolumn{2}{c|}{ Nilai } \\
\cline { 3 - 4 } & & Pretest & Postest \\
\hline 1. & Aldi Amsa Nasution & $\mathbf{5 0}$ & $\mathbf{8 0}$ \\
\hline 2. & Bayu Nugroho & $\mathbf{4 5}$ & $\mathbf{6 5}$ \\
\hline 3. & Brama Dhika Perwira & $\mathbf{6 5}$ & $\mathbf{8 5}$ \\
\hline 4. & Desi Afriana & $\mathbf{4 5}$ & $\mathbf{7 0}$ \\
\hline 5. & Eqshal Parel & $\mathbf{7 5}$ & $\mathbf{9 0}$ \\
\hline 6. & Fitria Anggra Ramadhani & $\mathbf{5 0}$ & $\mathbf{8 0}$ \\
\hline 7. & Isnaini Uswatun Hasanah & $\mathbf{5 0}$ & $\mathbf{8 0}$ \\
\hline 8. & Kelvin Pratama & $\mathbf{4 0}$ & $\mathbf{6 5}$ \\
\hline
\end{tabular}




\begin{tabular}{|r|l|c|c|}
\hline 9. & Lissa Mutia Sari & $\mathbf{6 0}$ & $\mathbf{8 5}$ \\
\hline 10. & Mesti Anggraini & $\mathbf{7 5}$ & $\mathbf{9 5}$ \\
\hline 11. & Mhd. Ramadhani & $\mathbf{4 5}$ & $\mathbf{6 5}$ \\
\hline 12. & M. Yoan Asrobi & $\mathbf{5 0}$ & $\mathbf{7 0}$ \\
\hline 13. & Nayla Salsabila Putri & $\mathbf{6 5}$ & $\mathbf{8 5}$ \\
\hline 14. & Nazwa Nur Wahida & $\mathbf{5 0}$ & $\mathbf{8 5}$ \\
\hline 15. & Nur Agustina & $\mathbf{7 5}$ & $\mathbf{8 5}$ \\
\hline 16. & Nur Ainun Fadila Sari & $\mathbf{7 5}$ & $\mathbf{9 0}$ \\
\hline 17. & Putra Pradana & $\mathbf{5 5}$ & $\mathbf{7 5}$ \\
\hline 18. & Rindiyani & $\mathbf{6 0}$ & $\mathbf{8 0}$ \\
\hline 19. & Yoga Satrio Pratamadani & $\mathbf{6 0}$ & $\mathbf{8 0}$ \\
\hline 20. & Zuhanda Saputra & $\mathbf{7 5}$ & $\mathbf{9 5}$ \\
\hline
\end{tabular}

Dari hasil pengumpulan data di atas, maka untuk mengetahui daya serap peserta didik dapat dilihat sebagai berikut:

\section{1) Pretest}

Hasil analisis statsitik deskriptif untuk hasil belajar IPS peserta didik setelah dilakukan pretest adalah sebagai berikut:

Tabel 4.12

Distribusi Frekuensi Hasil Belajar Peserta Didik Sebelum menggunakan metode diskusi (Pretest)

\begin{tabular}{|c|c|c|c|}
\hline NO & INTERVAL & FREKUENSI & PERSENTASE \\
\hline 1 & $40-46$ & 4 & $20 \%$ \\
\hline 2 & $47-53$ & 5 & $25 \%$ \\
\hline 3 & $54-60$ & 4 & $20 \%$ \\
\hline 4 & $61-67$ & 2 & $10 \%$ \\
\hline 5 & $68-75$ & 5 & $25 \%$ \\
\hline & JUMLAH & $\mathbf{2 0}$ & $\mathbf{1 0 0 \%}$ \\
\hline
\end{tabular}




\section{Grafik 2. Hasil Pretest}

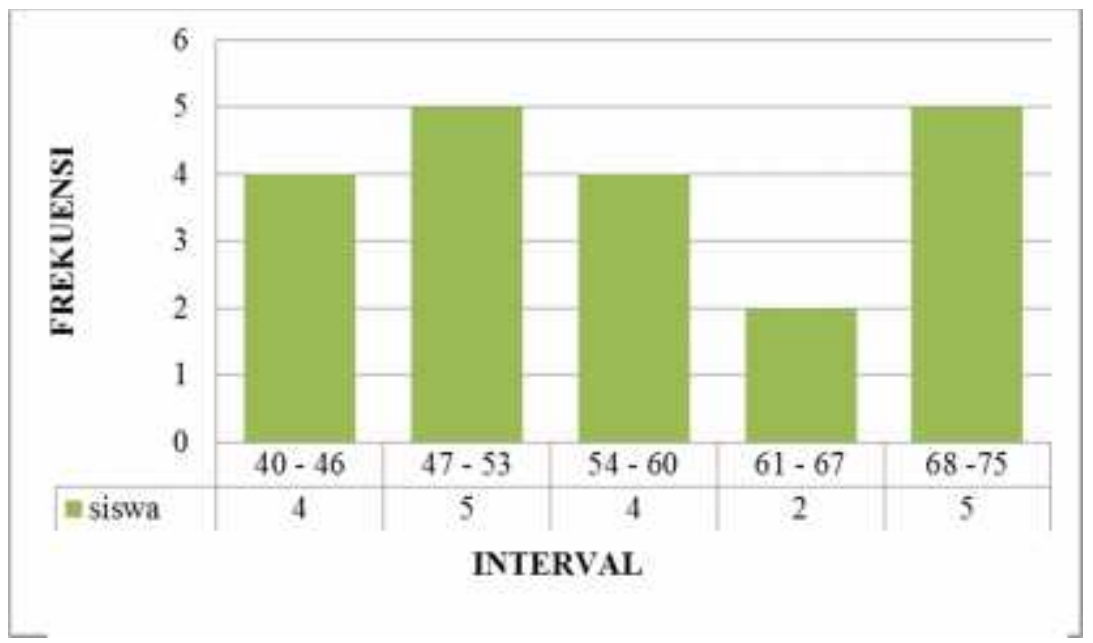

Berdasarkan pada tabel di atas maka dapat diketahui bahwa tingkat pengusaan materi peserta didik pada pretest sebagai berikut.nilai 40-46 dengan frekuensi 4 (20\%), nilai 47 -53 dengan frekuensi 5 (25\%), nilai 54-60 dengan frekuensi 4 (20\%), nilai 61-67 dengan frekuensi 2 (10\%), nilai 68-75 dengan frekuensi 5 (41,67\%).

Selanjutnya, peneliti menyajikan persentase nilai rata-rata hasil belajar pretest peserta didik dan persentasi ketuntasan klasikal

Tabel 3.3 Rekapitulasi Hasil Pretest

\begin{tabular}{|c|l|c|}
\hline No & Uraian & Hasil \\
\hline 1 & Nilai Rata-rata & 58 \\
2 & Jumlah Peserta Didik yang Tuntas Belajar & 5 \\
3 & Presentase Ketuntasan Belajar Klasikal & $25 \%$ \\
\hline
\end{tabular}

Dari Tabel 3.3, dapat dijelaskan bahwa peserta didik yang memperoleh nilai rata-rata adalah 58 dan ketuntasan belajar klasikal mencapai 25\% atau dari 20 peserta didik hanya 5 peserta didik yang tuntas belajar. Hasil pretest menunjukkan bahwa secara klasikal peserta didik belum tuntas belajar, karena peserta didik yang memperoleh nilai $\geq$ 70 hanya sebesar 25\% lebih kecil dari presentase yang dikehendaki yaitu sebesar 75 . 


\section{2) Posttest}

Hasil analisis statistik deskriptif untuk hasil belajar IPS peserta didik setelah dilakukan posttest adalah sebagai berikut:

Tabel 4.15

Distribusi Frekuensi Hasil Belajar Peserta Didik Setelah Penerapan Metode Diskusi ( siklus I )

\begin{tabular}{|c|c|c|c|}
\hline NO & INTERVAL & FREKUENSI & PERSENTASE \\
\hline 1 & $65-70$ & 5 & $25 \%$ \\
\hline 2 & $71-77$ & 1 & $10 \%$ \\
\hline 3 & $78-83$ & 5 & $25 \%$ \\
\hline 4 & $84-89$ & 5 & $25 \%$ \\
\hline 5 & $90-95$ & 4 & $20 \%$ \\
\hline & JUMLAH & $\mathbf{2 0}$ & $\mathbf{1 0 0 \%}$ \\
\hline
\end{tabular}

Grafik 2. Hasil Posttest

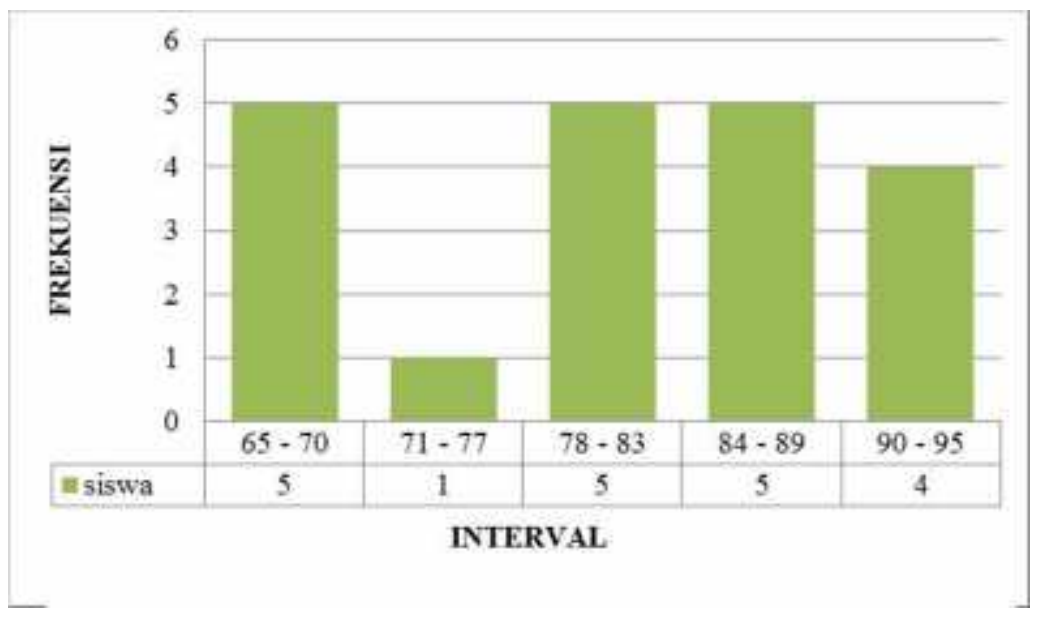

Berdasarkan pada tabel di atas maka dapat diketahui bahwa tingkat pengusaan materi peserta didik pada siklus I ( posttest) sebagai berikut. Nilai 65-70 dengan frekuensi $5(25 \%)$, nilai $71-77$ dengan frekuensi 1 (10\%), nilai 78-83 dengan frekuensi 5 (25\%), nilai 84-89 dengan frekuensi 5 (25\%), nilai 90-95 dengan frekuensi 4 (20\%).

Selanjutnya, peneliti menyajikan persentase nilai rata-rata hasil belajar pretest peserta didik dan persentasi ketuntasan klasikal 
Tabel 3.5 Rekapitulasi Hasil Tes Siklus 1

\begin{tabular}{|c|l|c|}
\hline No & Uraian & Hasil \\
\hline 1 & Nilai Rata-rata & 75 \\
2 & Jumlah Peserta Didik yang Tuntas & 15 \\
& Belajar & \\
3 & Presentase Ketuntasan Belajar Klasikal & $75 \%$ \\
\hline
\end{tabular}

Dari Tabel 3.5 dapat dijelaskan bahwa nilai rata-rata adalah 75 dan ketuntasan belajar klasikal mencapai $75 \%$ atau dari 20 peserta didik terdapat 15 peserta didik tuntas belajar. Hasil tersebut menunjukkan bahwa pada tindakan siklus I secara klasikal peserta didik sudah tuntas belajar, karena peserta didik yang memperoleh nilai $\geq 75$ mencapai $75 \%$ sama dengan presentase yang dikehendaki yaitu sebesar 75\%, maka tidak perlu dilanjutkan pada tindakan siklus selanjutnya.

\section{3) Pengujian Pertanyaan Penelitian}

Berdasarkan data yang diperoleh pada pretest menunjukan bahwa jumlah siswa yang tuntas sebanyak 5 siswa atau (25\%), tidak tuntas sebanyak 15 siswa atau (75\%), sedangkan siklus I siswa yang tuntas sebanyak 15 siswa atau (75\%), dan tidak tuntas 5 siswa atau (25\%). Untuk lebih jelas mengenai peningkatan hasil belajar siswa dapat dilihat keterangan pembelajaran siswa sebelum dan sesudah menggunakan metode diskusi pada tabel 6 .

Tabel 6. Perbandingan Hasil belajar siswa sebelum dan sesudah menggunakan metode diskusi

\begin{tabular}{|c|c|c|c|}
\hline Kategoori & Pretest & Siklus I & Ket \\
\hline Tuntas & $5(25 \%)$ & $15(75 \%)$ & \multirow{2}{*}{$\begin{array}{c}\text { Adanya } \\
\text { peningkatan }\end{array}$} \\
\hline Tidak Tuntas & $15(75 \%)$ & $5(25, \%)$ & \\
\hline Jumlah & $20(100 \%)$ & $20(100 \%)$ & \\
\hline
\end{tabular}

Dari tabel di atas, dapat disimpulkan pada pretest, siswa yang tuntas sebanyak 5 orang, dan yang tidak tuntas sebanyak 15 orang, dan siklus I siswa yang tuntas sebanyak 15 orang, dan tidak tuntas 5 orang, dengan pembelajaran terdapat peningkatan $50 \%$.

\section{Pembahasan}

Pada bagian pembahasan ini akan dibahas mengenai hasil penelitian yang telah diperoleh. Penelitian ini merupakan Penelitian Tindakan Kelas dengan prosedur penelitian berbentuk siklus dengan menggunakan model yang merupakan adaptasi dari model yang 
dikembangkan oleh Kemmis \& Taggart (Arikunto, 2008:16) Setiap siklus meliputi perencanaan, pelaksanaan, pengamatan dan refleksi.

Setelah melalui proses perhitungan, diperoleh hasil Pretest dan Posttest yang telah dilakukan. Dimana Pretest merupakan tes awal yang dilakukan peneliti sebelum melakukan siklus I sedangkan posttest merupakan tes yang dilakukan setelah menggunakan metode diskusi. Dapat terlihat bahwa pelajaran yang menggunakan metode diskusi dapat meningkatkan hasil belajar peserta didik pada mata pelajaran IPS Kelas VIIA SMPN 4 Tapung Hilir Kab. Kampar. Hal ini dapat terlihat pada analisis deskriptif yang dilakukan sebelumnya, yaitu hasil analisis deskriptif tes IPS peserta didik dengan rata-rata nilai hasil pretest yaitu 25 dan rata-rata nilai hasil posttest yaitu 75 serta selisih rata-rata kenaikan hasil belajar peserta didik adalah 50 dengan persentase $50 \%$.

Berdasarkan hasil pemaparan di atas, dapat disimpulkan bahwa metode diskusi terdapat peningkatan terhadap hasil belajar IPS pada peserta didik kelas VIIA SMPN 4 Tapung Hilir Kab. Kampar. Hal ini terjadi karena dengan metode diskusi membuat peserta didik lebih aktif dalam belajar, peserta didik dilatih mandiri dalam belajar yaitu mampu memecahkan masalah sendiri, berani mengungkapkan pendapat sendiri, dan membantu meningkatkan minat dan prestasi belajar. Pembelajaran dengan menerapkan metode diskusi juga dapat membantu peserta didik mencapai tujuan pembelajaran secara efektif dan efisien serta memungkinkan peserta didik untuk melakukan pembelajaran aktif dan mandiri tanpa bergantung pada guru.

Dengan menggunakan metode diskusi terjadi peningkatan terhadap hasil belajar peserta didik pada mata pelajaran IPS dapat kita lihat pada nilai hasil belajar peserta didik lebih tinggi dibandingkan dengan nilai hasil belajar sebelum menggunakan metode diskusi. Penyebabnya karena penerapan metode diskusi efektif dapat meningkatkan antusias peserta didik dalam belajar sehingga dapat meningkatkan kemandirian dan keefektifan belajar peserta didik.

\section{SIMPULAN}

Berdasarkan hasil analisis data tentang penggunaan metode diskusi untuk meningkatkan hasil belajar peserta didik pada mata pelajaran IPS di SMPN 4 Tapung Hilir kab. Kampar, maka akhirnya dapat disimpulkan bahwa: Hasil pretest belajar siswa pada mata pelajaran IPS sebelum menggunakan metode diskusi terbukti tidak memuaskan dengan persentase ketuntasan $25 \%$ atau dengan nilai rata-rata 58; Penggunaan metode diskusi dapat meningkatkan penguasaan siswa terhadap materi memahami lokasi melalui peta yang tampak pada hasil belajar aspek kognitif dapat dilihat dari nilai rata-rata siswa yang meningkat dari siklus I . Nilai rata-rata yang diperoleh dari 20 siswa pada kondisi pra siklus sebesar 58, naik menjadi 80,25 pada siklus I.. Adapun persentase ketuntasan hasil belajar pada pra siklus sebesar $25 \%$, pada siklus I naik menjadi $75 \%$, . Siswa yang memenuhi kriteria ketuntasan hasil belajar yakni 75; Penggunaan metode diskusi memberikan banyak kontribusi diantaranya dapat meningkatkan aktivitas siswa dalam belajar .siswa menjadi terlatih bekerjasama dalam kelompok serta dapat meningkatkan hasil belajar siswa. 


\section{DAFTAR REFERENSI}

Arikunto, S. (2010). Penelitian Tindakan Kelas. Jakarta: Bumi Aksara

Kadir, Abd, dkk., Dasar-Dasar Pendidikan. Cet.I; Jakarta: Kencana Prenada Media Group, 2012.

Nata, Abuddin. Perspektif Islam Tentang Strategi Pembelajaran.Cet. III; Jakarta: April 2014 